\title{
ANALISIS FAKTOR RISIKO KUALITAS BAKTERIOLOGIS AIR MINUM ISI ULANG DI KABUPATEN OGAN ILIR
}

\author{
Inoy Trisnaini, Elvi Sunarsih, Dwi Septiawati \\ Fakultas Kesehatan Masyarakat, Universitas Sriwijaya \\ ANALYSIS OF RISK FACTOR OF BACTERIOLOGICAL \\ QUALITY OF DRINKING WATER IN OGAN ILIR DISTRICT
}

\begin{abstract}
Background: Contamination of bacteria and viruses in drinking water have become the main problem of water pollution in developing countries until now. Research by the Bogor Agricultural Institute and the Agency for Drug and Food Control states that most of the drinking water products produced by DAMIU are considered not to meet the bottled water industry standards. The purpose of this research is to get what factors affect the presence of coliform bacteria in drinking water refills of DAMIU in Ogan Ilir Districts.

Method: This research is observation analytic research using cross sectional. The sample in this research is 40 DAMIU in Ogan Ilir Districts. Data were analyzed by univariate and bivariate, also laboratory test of Ecoli content on water samples was done.

Results: This research found that 13 DAMIU (32.5\%) which positive water samples contain coliform bacteria. The result of statistical analysis showed that the operating permit variables, sterilization equipment, raw water source, filling room, cleanliness of DAMIU, garbage bins, bacteriological inspection, work clothes, food inspection training, periodic supervision, personal hygiene, personal hygiene and hand washing facilities had no relationship with bacteriological quality of water.

Conclusion: Hygiene and sanitation of Drinking Water Refill Depot (DAMIU) in Ogan Ilir Districts is still classified into poor condition. Thus increasing the knowledge and awareness of DAMIU employees on sanitary hygiene as well as supervision from the health service and facilitating bacteriological examination of water were need to do.

Keyword: Drinking water depot refill, hygiene, sanitation
\end{abstract}

\begin{abstract}
ABSTRAK
Latar Belakang: Kontaminasi bakteri dan virus pada air minum menjadi permasalahan utama pencemaran air di negara sedang berkembang sampai dengan saat ini. Penelitian oleh Institute Pertanian Bogor dan Badan Pengawas Obat dan Makanan menyatakan bahwa sebagian besar produk air minum dihasilkan oleh DAMIU dinilai belum memenuhi standar industri air minum dalam kemasan. Tujuan dari penelitian ini ialah untuk memperoleh faktor-faktor apa saja yang mempengaruhi adanya kandungan bakteri coliform pada air minum isi ulang yang berasal dari depot air minum isi ulang.

Metode: Penelitian ini merupakan penelitian observasional analitik dengan menggunakan metode cross sectional. Sampel pada penelitian ini ialah 40 DAMIU yang ada di Kabupaten Ogan Ilir. Data dianalisis secara univariat dan bivariat, serta dilakukan uji laboratorium kandungan bakteri coliform pada sampel air.

Hasil penelitian: Berdasarkan pemeriksaan laboratorium ditemukan 13DAMIU (32,5\%) yang sampel airnya positif mengandung bakteri koliform. Hasil analisis bivariat diperoleh bahwa variabel izin operasi, alat sterilisasi, sumber air baku, ruang pengisian, kebersihan DAMIU, tempat sampah, pemeriksaan bakteriologis, pakaian kerja, pelatihan penajmah makanan, pengawasan berkala, higiene personal, kebersihan diri dan fasilitas cuci tangan tidak memiliki hubungan yang bermakna dengan kualitas bakteriologis air.

Kesimpulan: Higiene dan sanitasi Depot Air Minum Isi Ulang (DAMIU) di Kabupaten Ogan Ilir masih tergolong ke dalam kategori buruk. Sehingga peningkatan pengetahuan dan kesadaran karyawan DAMIU mengenai hygiene sanitasi serta pengawasan dari dinas kesehatan dan memfasilitas pemeriksaan bakteriologis air perlu dilakukan.
\end{abstract}

Alamat Koresponding: Inoy Trisnaini, Fakultas Kesehatan Masyarakat Universitas Sriwijaya. Jl. Palembang Prabumulih KM. 32, Indralaya Indah Kabupaten Ogan Ilir, Sumatera Selatan, email : inoytrisnaini@ gmail.com 
Keyword: Depot air minum isi ulang, higiene, sanitasi

\section{PENDAHULUAN}

Pada kehidupan sehari-hari, air begitu dibutuhkan oleh tubuh manusia, seperti halnya udara dan makanan yang diperlukan bagi kelangsungan hidup. Tanpa air, manusia tidak dapat bertahan lebih lama. Adapun air minum ialah air yang secara kualitas memenuhi syarat kesehatan dan dapat langsung diminum, baik melalui proses pengolahan atau tanpa proses pengolahan. Manusia dalam menjaga keseimbangan metabolisme dan fisiologi tubuh membutuhkan air minum yang tentunya memenuhi syarat kesehatan. Disamping itu, air juga digunakan untuk melarutkan dan mengolah sari-sari makanan agar dapat dicerna. Persyaratan yang harus dipenuhi agar air minum aman bagi kesehatan yaitu memenuhi persyaratan secara fisika, mikrobiologis, kimiawi, dan radioaktif. Terdapat beberapa media transmisi penularan penyakit, dan air menjadi media yang sangat baik bagi transmisi berbagai mikroorganisme. ${ }^{1}$ Kandungan total bakteri Coliform dan Escherichia coli merupakan parameter wajib penentuan kualitas air minum secara mikrobiologi.

Kontaminasi bakteri dan virus pada air minum menjadi permasalahan utama pencemaran air di negara sedang berkembang sampai dengan saat ini. Sebaliknya di negara maju berhasil menurunkan kejadian penyakit yang disebabkan oleh air, yaitu dengan diterapkannya pemurnian air secara baik. ${ }^{2}$ Sedangkan seiring dengan pertambahan penduduk, maka meningkat pula kebutuhan masyarakat akan air minum yang layak untuk dikonsumsi. Namun masyarakat cenderung mengkonsumsi air minum siap pakai dalam bentuk kemasan atau air isi ulang. Sehingga pada saat ini pelayanan air minum melalui sistem Perpipaan Air Minum (PAM), Air Minum Dalam Kemasan (AMDK) maupun air dari Depot Air Minum Isi Ulang (DAMIU) menjadi kebutuhan penduduk terhadap air minum. Air minum isi ulang telah menjadi pilihan umum masyarakat Indonesia, termasuk di Sumatera Selatan khususnya Indralaya.

Berbagai penelitian sebelumnya di berbagai kota besar di Indonesia, menunjukkan AMIU kurang aman serta dapat merugikan kesehatan manusia disebabkan terkontaminasi oleh bakteri. ${ }^{3,4,5,6,7}$ Penelitian yang dilakukan oleh Institute Pertanian Bogor (IPB) dan Badan Pengawas Obat dan Makanan (BPOM) menyatakan bahwa sebagian besar produk air minum dihasilkan oleh DAMIU dinilai belum memenuhi standar industri air minum dalam kemasan. Penelitian dilakukan di beberapa kota besar seperti Jakarta, Bandung, Medan serta Surabaya. Hasil penelitian di dua lembaga ini menunjukkan bahwa air minum isi ulang secara bakteriologis telah terkontaminasi bakteri Coliform, E. Coli, salmonella, sedangkan secara kimiawi sampel air terdeteksi mengandung logam berat cadmium. $^{8}$ Disamping itu penelitian yang dilakukan oleh Malisa di Kecamatan Seberang Ulu Kota Palembang, menyatakan bahwa 76\% dari produk air minum dihasilkan oleh DAMIU tidak memenuhi syarat kesehatan dan ditemukan bakteri coliform. ${ }^{9}$

Diare merupakan salah satu penyakit yang disebabkan oleh air minum yang telah terkontaminasi oleh mikroorganisme, dan diare merupakan salah satu penyakit di Indonesia dengan angka kejadian tinggi khususnya pada bayi dan balita. Berdasarkan Profil Kesehatan Kabupaten Ogan Ilir Tahun 2015, bahwa angka kejadian diare tertinggi pada semua usia dari tiga kecamatan yaitu Kecamatan Indralaya, Kecamatan Indralaya Utara dan Kecamatan Indralaya Selatan ialah Kecamatan Indralaya, dengan angka kejadian diare 843 kasus. $^{10}$ Mengingat semakin banyaknya penggunaan dan pemanfaatan AMIU untuk kebutuhan vital masyarakat dan adanya indikasi kurang amannya AMIU di berbagai kota besar di Indonesia termasuk di 
Kota Palembang, maka perlu adanya pengawasan atau monitor serta pengujian yang memadai atas keamanan AMIU yang beredar di Kabupaten Ogan Ilir. Masyarakat juga pada umumnya kurang memberi perhatian dan pertimbangan rasional menyangkut keamanan dan higienitas AMIU karena yang menjadi pertimbangan utama adalah harga yang terjangkau. Hal ini juga didorong oleh kondisi dimana ketersediaan air minum yang bersih dan aman kurang tersedia. Hal ini diperlukan karena masyarakat tidak dapat melihat secara nyata kondisi aman tidaknya AMIU yang dikonsumsi di Kecamatan Ogan Ilir. Untuk mengetahui kondisi terkontaminasi tidaknya AMIU diperlukan penelitian atau pengujian secara klinis di laboratorium. Tujuan dari penelitian ini ialah untuk memperoleh faktor-faktor apa saja yang mempengaruhi adanya kandungan bakteri coliform pada air minum isi ulang yang berasal dari depot air minum isi ulang.

\section{METODE}

Rancangan dalam penelitian ialah menggunakan metode observasional analitik, pendekatan cross sectional untuk mengetahui dinamika populasi antara faktor risiko dan efek dengan cara observasi serta data dikumpulkan sekaligus dalam waktu yang bersamaan. Penelitian ini dilakukan di Kabupaten Ogan Ilir.

Populasi yang digunakan pada penelitian ini adalah seluruh Depot Air Minum Isi Ulang (DAMIU) yang ada di Kabupaten Ogan Ilir. Sampel dalam penelitian ini adalah sebagian dari Depot Air Minum Isi Ulang (DAMIU) yang ada di Kabupaten Ogan Ilir baik yang terdaftar maupun yang tidak terdaftar, sampel diperoleh dengan Uji Hipotesis Proporsi Independen 2 kelompok dua sisi dan teknik simple random sampling yaitu sebanyak 40 sampel. $^{11}$ Selain itu dilakukan pula uji laboratorium MPN total coliform terhadap sampel air dari setiap DAMIU. Adapun variabel independen yang diteliti dalam penelitian ini ialah izin operasi, sumber air baku, alat sterilisasi, ruang pengisian, kebersihan DAMIU, tempat sampah, pemeriksaan sampel, pengawasan berkala, hygiene personal, kesehatan diri, serta fasilitas cuci tangan. Data dianalisis secara univariat dan bivariat.

\section{HASIL PENELITIAN \\ Karakteristik Responden}

Tabel berikut menunjukkan distribusi frekuensi pendidikan Karyawan DAMIU.

Tabel 1.

Pendidikan Karyawan DAMIU di Ogan Ilir

\begin{tabular}{lcc}
\hline Pendidikan & Frekuensi & Persentase \\
\hline Tamat SD & 4 & 10 \\
Tamat SLTP & 5 & 12,5 \\
Tamat SLTA & 27 & 67,5 \\
Tamat Diploma/Sarjana & 4 & 10 \\
\hline Total & $\mathbf{4 0}$ & $\mathbf{1 0 0}$ \\
\hline
\end{tabular}

Berdasarkan Tabel 1 diketahui bahwa mayoritas pendidikan responden sebanyak 27 orang $(67,5 \%)$ karyawan DAMIU yang ada di Kabupaten Ogan Ilir memiliki pendidikan terakhir tamat SLTA. Sedangkan sisanya merupakan tamatan SD, SLTP serta Diploma dan sarjana.

Kondisi menunjukkan bahwa secara tingkat pendidikan karyawan yang bertugas dalam pengisian galon ialah mereka yang telah mendapatkan pendidikan hingga di tingkat SLTA, sehingga seharusnya mampu memahami dengan baik jika diberi informasi dan petunjuk dalam proses pengisian galon yang memenuhi syarat secara hygiene dan sanitasi yang baik.

Tabel 2.

\section{Umur Karyawan DAMIU di Ogan Ilir}

\begin{tabular}{lcc}
\hline Umur & Frekuensi & Persentase \\
\hline 17 - 30 Tahun & 25 & 62,5 \\
31-50 Tahun & 13 & 32,5 \\
> 50 Tahun & 2 & 5.0 \\
\hline Total & $\mathbf{4 0}$ & $\mathbf{1 0 0}$ \\
\hline
\end{tabular}


Berdasarkan Tabel 2 diketahui bahwa mayoritas usia responden sebanyak 25 orang $(62,5 \%)$ karyawan DAMIU yang ada di Kabupaten Ogan Ilir memiliki usia dalam rentang 17 - 30 tahun. Hasil ini menunjukkan bahwa mayoritas karyawan yang bertugas melakukan pengisian galon termasuk ke dalam kelompok usia produktif. Kelompok usia yang dinilai dapat bertanggungjawab terhadap tugas yang diberikan. Termasuk mengenai pengisian galon yang menjaga hygiene personal yang baik dalam pengisian galon serta menjaga sanitasi depot air minum.

\section{Hubungan Variabel Penelitian}

Tabel 3.

Hubungan Variabel Penelitian dengan Kualitas Bakteriologis Air Minum Hasil Pengolahan DAMIU di Ogan Ilir

\begin{tabular}{|c|c|c|c|c|c|c|c|}
\hline \multirow{3}{*}{ Izin Operasi } & \multicolumn{4}{|c|}{$\begin{array}{c}\text { Kualitas Bakteriologis } \\
\text { Air Minum }\end{array}$} & \multirow{2}{*}{\multicolumn{2}{|c|}{ Total }} & \multirow{3}{*}{$\underset{\text { value }}{p}$} \\
\hline & \multicolumn{2}{|c|}{$\begin{array}{c}\text { Tidak Memenuhi } \\
\text { Syarat }\end{array}$} & \multicolumn{2}{|c|}{$\begin{array}{l}\text { Memenuhi } \\
\text { Syarat }\end{array}$} & & & \\
\hline & $\mathbf{n}$ & $\%$ & n & $\%$ & $\mathbf{n}$ & $\%$ & \\
\hline Tidak ada izin & 1 & 16,7 & 5 & 83,3 & 6 & 100 & 0,369 \\
\hline Ada izin & 12 & 35,3 & 22 & 64,7 & 34 & 100 & \\
\hline \multicolumn{8}{|c|}{ Sumber Air Baku } \\
\hline Pegunungan & 5 & 27,8 & 13 & 72,2 & 18 & 100 & 0,564 \\
\hline PDAM & 8 & 36,4 & 14 & 63,6 & 22 & 100 & \\
\hline \multicolumn{8}{|l|}{ Alat Sterilisasi } \\
\hline Tidak Berfungsi & 5 & 29,4 & 12 & 70,6 & 17 & 100 & 0,720 \\
\hline Berfungsi & 8 & 34,8 & 15 & 65,2 & 23 & 100 & \\
\hline \multicolumn{8}{|c|}{ Ruang Pengisian } \\
\hline Terbuka & 2 & 40 & 5 & 60 & 5 & 100 & 0,702 \\
\hline Tertutup & 11 & 31,4 & 24 & 68,6 & 35 & 100 & \\
\hline \multicolumn{8}{|c|}{ Kebersihan DAMIU } \\
\hline Tidak Bersih & 2 & 20 & 8 & 80 & 10 & 100 & 0,330 \\
\hline Bersih & 11 & 36,7 & 19 & 63,3 & 30 & 100 & \\
\hline \multicolumn{8}{|l|}{ Tempat Sampah } \\
\hline Terbuka & 13 & 36,1 & 23 & 63,9 & 36 & 100 & 0,144 \\
\hline Tertutup & 0 & 0 & 4 & 100 & 4 & 100 & \\
\hline \multicolumn{8}{|c|}{ Pemeriksaan Sampel } \\
\hline Tidak & 10 & 30,3 & 23 & 69,7 & 33 & 100 & 0,519 \\
\hline $\mathrm{Ya}$ & 3 & 42,9 & 4 & 57,1 & 7 & 100 & \\
\hline \multicolumn{8}{|c|}{ Pengawasan Berkala } \\
\hline Tidak Pernah & 3 & 27,3 & 8 & 72,7 & 11 & 100 & 0,664 \\
\hline Ya & 10 & 34,5 & 19 & 65,5 & 29 & 100 & \\
\hline \multicolumn{8}{|l|}{ Higiene Personal } \\
\hline Buruk & 12 & 34,3 & 23 & 67,5 & 35 & 100 & 0,523 \\
\hline Baik & 1 & 20 & 4 & 80 & 5 & 100 & \\
\hline \multicolumn{8}{|l|}{ Kesehatan Diri } \\
\hline Buruk & 13 & 33,3 & 26 & 66,7 & 39 & 100 & 0,482 \\
\hline Baik & 0 & 0 & 1 & 100 & 1 & 100 & \\
\hline \multicolumn{8}{|c|}{ Fasilitas Cuci Tangan } \\
\hline Tidak tersedia & 12 & 34,3 & 23 & 67,5 & 35 & 100 & 0,523 \\
\hline Tersedia & 1 & 20 & 4 & 80 & 5 & 100 & \\
\hline
\end{tabular}

Berdasarkan Tabel 3 diketahui bahwa dari seluruh variabel yang diteliti yaitu izin beroperasi, sumber air baku, alat sterilisasi, ruang pengisian, kebersihan DAMIU, kondisi tempat sampah, pemeriksaan sampel, pengawasan berkala, higiene personal, kebersihan diri, dan fasilitas cuci tangan DAMIU yang diteliti tidak memiliki hubungan yang bermakna dengan kualitas bakteriologis air minum hasil pengolahan depot air minum di Kabupaten Ogan Ilir. 
PEMBAHASAN

\section{Hubungan Izin Operasi DAMIU dengan Kualitas Bakteriologis Air Minum Hasil Pengolahan Depot Air Minum di Kabupaten Ogan Ilir}

Hasil penelitian menunjukkan bahwa sebanyak 34 orang (85\%) DAMIU yang ada di Kabupaten Ogan Ilir memiliki izin beroperasi. Selain itu, berdasarkan hasil penelitian ini $50 \%$ dari DAMIU yang menjadi unit analisis mulai beroperasi pada rentang tahun 2010 - 2016. Sedangkan 47\% DAMIU mulai beroperasi sebelum tahun 2010. Hasil penelitian menunjukkan bahwa tidak ada hubungan yang bermakna antara izin operasi DAMIU dengan kualitas bakteriologis air minum hasil pengolahan depot air minum di Kabupaten Ogan Ilir. Berbeda dengan penelitian yang dilakukan oleh Haryuni dkk bahwa mayoritas DAMIU $(92,4 \%)$ yang beroperasi yang menjadi sampel dalam penelitian tidak memiliki izin operasi. ${ }^{7}$ Penelitian tersebut pun memperoleh hasil bahwa adanya hubungan yang bermakna antara ada tidaknya izin DAMIU tersebut beroperasi dengan kandungan bakteriologis di dalam sampel air.

\section{Hubungan Sumber Air Baku DAMIU dengan Kualitas Bakteriologis Air Minum Hasil Pengolahan Depot Air Minum di Kabupaten Ogan Ilir}

Hasil penelitian menunjukkan bahwa sebanyak 22 DAMIU (55\%) sumber air baku yang digunakan ialah berasal dari PDAM. Sedangkan sisanya sebanyak 18 DAMIU (45\%) menggunakan air baku yang bersumber dari air pegunungan. Beberapa penelitian lainnya juga membahas terkait sumber air baku, Penelitian oleh Wandrivel dkk, Khoeriyah dan Pratiwi juga memperoleh hasil bahwa mayoritas sumber air baku yang digunakan berasal dari pegunungan., ${ }^{3,4,12}$

Hasil penelitian menunjukkan bahwa tidak ada hubungan yang bermakna antara sumber air baku DAMIU dengan kualitas bakteriologis air minum hasil pengolahan depot air minum di Kabupaten Ogan Ilir. Sejalan dengan penelitian ini, penelitian oleh Putri juga menunjukkan bahwa tidak ada hubungan yang bermakna antara sumber air baku dengan kandungan koliform pada air. ${ }^{9}$ Meskipun demikian, sumber air baku yang digunakan akan menentukan kualitas dari air galon tersebut, termasuk menentukan keberadaan pencemar biologis di dalam air. ${ }^{13}$ Kualitas bahan baku tentu sangat menentukan kualitas produk air minum yang dihasilkan. Produk air dari depot air minum dengan bahan baku yang berasal dari perbukitan di sekitar Bungus memberikan hasil positif mengandung bakteri coliform. Oleh karena itu perlu dikaji lagi apakah bahan baku yang berasal dari daerah tersebut layak digunakan sebagai bahan baku untuk diolah menjadi air minum. Bahan baku utama yang seharusnya digunakan adalah air yang diambil dari sumber yang terjamin kualitasnya, yaitu terlindungi dari cemaran kimia dan mikrobiologi yang bersifat merusak/mengganggu kesehatan, serta diperiksa secara berkala terhadap organoleptik (bau, rasa, warna), fisika, kimia, dan mikrobiologi. Sampel yang bahan bakunya berasal dari air PDAM menunjukkan hasil positif mengandung bakteri coliform. Maka perlu juga dikaji kembali apakah air PDAM layak dijadikan sebagai bahan baku untuk depot air minum yang umumnya mengambil bahan baku dari mata air pegunungan. ${ }^{13}$

\section{Hubungan Fungsi Alat Sterilisasi DAMIU dengan Kualitas Bakteriologis Air Minum Hasil Pengolahan Depot Air Minum di Kabupaten Ogan Ilir.}

Hasil penelitian menunjukkan bahwa lebih dari separuh yaitu 23 DAMIU (57,5\%) memiliki alat sterilisasi galon yang masih berfungsi. Namun tidak sedikit pula yaitu sebanyak 17 DAMIU (42,5\%) memiliki alat sterilisasi galon yang tidak berfungsi lagi. 
Selain itu dari hasil penelitian menunjukkan pula bahwa lebih dari separuh yaitu 23 DAMIU $(57,5 \%)$ tidak melakukan sterilisasi terhadap galon yang akan diisi ulang, tentunya hal ini akan berkaitan dengan higiene dan kebersihan air galon. Hasil penelitian menunjukkan bahwa tidak ada hubungan yang bermakna antara alat sterilisasi galon dengan kualitas bakteriologis air minum hasil pengolahan depot air minum di Kabupaten Ogan Ilir. Berbeda dengan penelitian oleh Haryuni dan Djaja yang menunjukkan adanya hubungan yang bermakna antara berfungsi tidaknya alat sterilisasi galon dengan kualitas bakteriologis air. $^{7}$

Pentingnya kebersihan galon yang diawali dengan berfungsi tidak alat sterilisasi galon serta rutin tidaknya dilakukan sterilisasi terhadap setiap galon yang akan dilakukan pengisian air. Penelitian yang dilakukan oleh Walangitan dkk menunjukkan bahwa dari pemeriksaan pada 8 DAMIU menunjukkan bahwa mayoritas kondisinya kebersihan botol galon bersih, tissue alcohol untuk desinfeksi leher botol tersedia, kran alat pencuci memenuhi syarat. ${ }^{5} \mathrm{Hal}$ ini menunjukkan telah adanya kesadaran dari pemilik dan karyawan depot akan pentingnya sterilisasi galon untuk mencegah adanya cemaran biologi berupa bakteri dan mikroorganisme yang mungkin bersarang di galon.

\section{Hubungan Ruang Pengisian Galon DAMIU dengan Kualitas Bakteriologis Air Minum Hasil Pengolahan Depot Air Minum di Kabupaten Ogan Ilir}

Hasil penelitian menunjukkan bahwa mayoritas responden yaitu sebanyak 35 DAMIU (87,5\%) yang ada di Kabupaten OganIlir memiliki memiliki ruang pengisian galon dalam kondisi tertutup. Hal ini dalam rangka menjaga dan menghindari adanya kontaminasi dan cemaran terutama cemaran debu terhadap air galon.

Beberapa penelitian juga membahas mengenai ruang pengisian galon diantaranya ialah penelitian oleh Wandrivel dengan hasil penelitian $88,9 \%$ depot air minum yang diteliti memiliki ruang pengisian galon dalam kondisi tertutup kaca. ${ }^{3}$ Selain itu penelitian oleh Haryuni dan Djaja menunjukkan adanya hubungan yang signifikan antara kondisi ruang pengisian galon yang tertutup dengan kualitas bakteriologis air. $^{7}$ Meskipun berdasarkan hasil penelitian menunjukkan bahwa tidak ada hubungan yang bermakna antara alat sterilisasi galon dengan kualitas bakteriologis air minum hasil pengolahan depot air minum di Kabupaten Ogan Ilir, namun dalam pembilasan dan pengisian galon harus dilakukan di ruang pengisian yang tertutup. Hal ini untuk mengurangi potensi adanya mikroba atau debu yang dapat masuk terbawa ke dalam air galon. Meskipun pada tahapan lainnya dalam pengisian galon telah dilakukan dengan baik, namun jika dalam proses ini tidak dilakukan dengan baik, maka tetap memiliki potensi untuk tercemarnya air galon. Sehingga hal inilah yang menjadi tujuan ruang pengisian galon perlu dalam kondisi tertutup. ${ }^{7}$

\section{Hubungan Penggunaan Pakaian Kerja Karyawan DAMIU dengan Kualitas Bakteriologis Air Minum Hasil Pengolahan Depot Air Minum di Kabupaten Ogan Ilir}

Hasil penelitian menunjukkan bahwa seluruh karyawan DAMIU (100\%) yang diteliti tidak memiliki pakaian kerja khusus, yaitu pakaian yang dipakai secara khusus diperuntukkan ketika karyawan sedang bekerja untuk pengisian galon. Kondisi ini pula salah satunya yang menyebabkan tidak adanya hubungan yang bermakna antara pakaian kerja karyawan dengan kualitas bakteriologis air minum hasil pengolahan depot air minum di Kabupaten Ogan Ilir. Hal tersebut tidak sesuai dengan yang dikemukakan oleh Fathonah bahwa pakaian kerja yang bersih akan menjamin sanitasi dan higiene pengolahan karena tidak terdapat debu atau kotoran melekat pada pakaian yang 
secara tidak langsung dapat menyebabkan pencemaran. Sebaiknya pemilik depot menyediakan seragam kerja untuk karyawannya, sehingga dapat mengurangi risiko kontaminasi. ${ }^{15}$

Kondisi di lapangan berdasarkan penelitian lain juga menunjukkan rendahnya penggunaan pakaian kerja khusus pada karyawan DAMIU. Hasil penelitian oleh Wulandari menunjukkan bahwa hanya 1 responden yang menggunakan seragam kerja dan 11 responden lainnya tidak menggunakan seragam. ${ }^{16}$ Hal tersebut tidak sesuai dengan yang dikemukakan oleh Fathonah bahwa pakaian kerja yang bersih akan menjamin sanitasi dan higiene pengolahan karena tidak terdapat debu atau kotoran melekat pada pakaian yang secara tidak langsung dapat menyebabkan pencemaran. ${ }^{14}$ Sebaiknya pemilik depot menyediakan seragam kerja untuk karyawannya, sehingga dapat mengurangi resiko kontaminasi. Selain itu penelitian lain juga menunjukkan bahwa karyawan menggunakan pakaian sehari-hari, hal ini menyebabkan apabila terdapat kotoran yang menempel pada pakaian tersebut tidak dapat terlihat sehingga berpotensi mencemari air galon. Penelitian ini juga menunjukkan adanya hubungan yang bermakna antara pemakaian pakaian kerja khusus pada karyawan depot air minum dengan kualitas bakteriologis air. ${ }^{7}$ Kondisi ini dapat disebabkan oleh berapa hal yaitu tidak disediakannya pakaian kerja khusus oleh pemiliki DAMIU, dan kondisi ini dapat berangkat belum pernahnya pemilik dan karyawan mendapatkan kursus/pelatihan penjamah makanan.

\section{Hubungan Keikutsertaan dalam Kursus Penjamah Makanan DAMIU dengan Kualitas Bakteriologis Air Minum Hasil Pengolahan Depot Air Minum di Kabupaten Ogan Ilir}

Berdasarkan hasil penelitian diketahui bahwa seluruh karyawan DAMIU (100\%) yang diteliti belum pernah mengikuti kursus/pelatihan penjamah makanan dan minuman. Hasil penelitian menunjukkan bahwa tidak ada hubungan yang bermakna antara keikutsertaan dalam kursus penjamah makanan dengan kualitas bakteriologis air minum hasil pengolahan depot air minum di Kabupaten Ogan Ilir. Kondisi ini sejalan dengan penelitian yang dilakukan di Kelurahan Karombasan Selatan, dimana seluruh depot yang diteliti menunjukkan keseluruh karyawan depot tersebut tidak memiliki sertifikat penjamah makanan. ${ }^{16}$ Serta penelitian oleh Haryuni dan Djaja bahwa mayoritas karyawan depot yang menjadi responden $94,9 \%$ belum pernah mengikuti kursus penjamah makanan. Meskipun dalam penelitian ini tidak menunjukkan adanya hubungan yang signifikan antara kursus penjamah makanan dengan kualitas bakteriologis air. ${ }^{7}$

Apabila pemilik maupun karyawan telah mendapatkan kursus/pelatihan penjamah makanan.Maka diharapakn mereka telah memperoleh pengetahuan mengenai pengelolaan makanan dan minum yang higiene dan saniter, serta selanjutnya memiliki kesadaran untuk menerapkan pada usaha depot air minum isi ulang mereka. Sebab, pengetahuan operator depot air minum tentang kebersihan juga mempengaruhi kualitas air yang dihasilkan. Meskipun terdapat beberapa alasan atas kondisi tidak terdapat satupun karyawan DAMIU dalam penelitian yang pernah mendapatkan kursus penjamah makanan, diantaranya ialah kurangnya sosialisasi kepada pemilik DAMIU terkait kursus atau pelatihan-pelatihan penjamah makanan, serta berkaitan pula dengan faktor biaya. Hubungan Kebersihan DAMIU dengan
Kualitas Bakteriologis Air Minum Hasil
Pengolahan Depot Air Minum di
Kabupaten Ogan Ilir 
Hasil penelitian menunjukkan bahwa tidak ada hubungan yang bermakna antara kebersihan DAMIU dengan kualitas bakteriologis air minum hasil pengolahan depot air minum di Kabupaten Ogan Ilir. Mayoritas DAMIU yaitu sebanyak 30 DAMIU (75\%) yang diteliti yang ada di Kabupaten OganIlir menunjukkan kondisi depot yang bersih dari kotoran dan debu. Hal ini tentunya dapat menjaga dan menghindari adanya kontaminasi dan cemaran terutama cemaran debu terhadap air galon.

Pada dasarnya jika dilihat dari aspek kersihan, dalam hal ini ialah tidak tampaknya kotoran ataupun debu di dalam ruang depot. Maka dapat dinilai secara umum DAMIU yang ada di Kabupaten Ogan Ilir dalam kondisi bersih. Beberapa penelitian juga menunjukkan hasil yang sejalan dengan penelitian ini. Penelitian oleh Walangitan menunjukkan dari keseluruhan depot yang diteliti kesemuanya terlihat dalam kondisi bersih dari kotoran dan debu. ${ }^{5}$ Higiene dan sanitasi menurut Peraturan Menteri Kesehatan RI No.43 tahun 2014 meliputi lokasi depot air minum, konstruksi bangunan, dan pelayanan terhadap konsumen. Lokasi dari bangunan untuk DAMIU harus berada di lokasi yang bebas dari pencemaran, seperti tempat pembuangan kotoran dan sampah, penumpukan barang bekas atau bahan berbahaya yang beracun, dan perusahaan lain yang diduga dapat menimbulkan pencemaran terhadap air minum. ${ }^{17}$ Perusahaan lain yang menimbulkan pencemaran seperti bengkel, cat, las, kapur dan sejenisnya. Berdasarkan seluruh DAMIU di Kabupaten Ogan Ilir yang diteliti sudah memenuhi syarat dari segi lokasi depot air minum isi ulang.

\section{Hubungan Kondisi Tempat Sampah DAMIU dengan Kualitas Bakteriologis Air Minum Hasil Pengolahan Depot Air Minum di Kabupaten Ogan Ilir.}

Hasil penelitian menunjukkan bahwa hampir seluruh yaitu sebanyak 36 DAMIU
(90\%) yang diteliti yang ada di Kabupaten Ogan Ilir memiliki tempat pembuangan sampah dalam kondisi yang terbuka. Hal ini tentunya tidak baik bagi higiene sanitasi air galon, sebab dapat berpotensinya paparan dari lalat yang membawa bakteri pencemar dari tempat sampah yang tidak tertutup.

Sebagai contoh lainnya, penelitian oleh Wulandari dkk menunjukkan bahwa 33\% depot yang diteliti memiliki lantai depot yang becek dan tidak rata, pintu depot tidak dapat mencegah masuknya serangga dan tikus, tidak ventilasi, tidak ada langit-langit, tidak ada ruang khusus untuk pengolahan, penyimpanan dan penyediaan tidak terdapat sekat, tidak terdapat tempat sampah yang ada tutupnya. ${ }^{15}$ Hasil penelitian menunjukkan bahwa tidak ada hubungan yang bermakna antara keadaan tempat sampah dengan kualitas bakteriologis air minum hasil pengolahan depot air minum di Kabupaten Ogan Ilir. Sejalan dengan penelitian oleh Yunus dkk, bahwa terdapat hubungan antara fasilitas pengelolaan sampah dengan keberadaan bakteri $E$ coli pada air minum. ${ }^{18}$

Kondisi fisik depot pada dasarnya telah diatur dalam Keputusan Menteri dan Perdagangan RI nomor 651/MPP/Kep/10/2004 tentang Persyaratan Teknis Depot Air Minum dan Perdagangannya. Diantaranya yaitu lantai depot kedap air dan rata, pintu depot dapat mencegah masuknya serangga dan tikus, terdapat ventilasi, terdapat langit-langit, terdapat ruang khusus untuk pengolahan, penyimpanan dan penyediaan yang memiliki sekat, termasuk terdapat tempat sampah yang dilengkapi dengan tutup. ${ }^{14}$

\section{Hubungan Pemeriksaan Sampel Air DAMIU dengan Kualitas Bakteriologis Air Minum Hasil Pengolahan Depot Air Minum di Kabupaten Ogan Ilir.}

Hasil penelitian menunjukkan bahwa mayoritas responden yaitu sebanyak 33 DAMIU (82,5\%) yang ada di Kabupaten 
Ogan Ilir tidak melakukan pemeriksaan bakteriologis secara rutin pada sampel air yang digunakan. Hal ini disebabkan oleh beberapa faktor, baik disebabkan oleh kurangnya pemahaman dan kesadaran pemilik DAMIU akan pentingnya pemeriksaan bakteriologis terhadap air isi ulang, serta terkait faktor biaya yang harus dikeluarkan untuk melakukan pemeriksaan yang masih dijadikan sebagai alas an oleh pemilik DAMIU. Selain ini dari hasil penelitian, berdasarkan pembagian menurut frekuensi pemeriksaan bakteriologis air diketahui bahwa 52,5\% dari pemilik DAMIU yang diteliti tidak pernah melakukan pemeriksaan bakteriologis terhadap air baku mereka.

Hasil penelitian menunjukkan bahwa tidak ada hubungan yang bermakna antara pemeriksaan sampel air dengan kualitas bakteriologis air minum hasil pengolahan depot air minum di Kabupaten Ogan Ilir. Meskipun terdapat penelitian yang memperoleh hasil berbeda bahwa adanya hubungan yang signifkan antara depot yang memeriksakan sampel air dengan kualitas bakteriologi air minum. ${ }^{7}$ Pemilik DAMIU seringkali melalaikan kewajibannya untuk melakukan uji secara rutin terhadap sampel air. Alasan yang seringkali mendasar ialah faktor biaya pemeriksaan yang tinggi. Hal ini mengakibatkan tidak terkontrolnya kualitas air minum isi ulang yang dijual sehingga rentan terkontaminasi bakteri. Pemeriksaan sampel air dimaksudkan untuk memastikan kualitas air yang dijual aman untuk dikonsumsi serta tidak mengandung kuman penyakit. Pemeriksaan sampel ini wajib dilakukan secara berkala/atau rutin dan termasuk ke dalam pengawasan internal pemilik DAMIU.

Hubungan Pengawasan Berkala DAMIU dengan Kualitas Bakteriologis Air Minum Hasil Pengolahan Depot Air Minum di Kabupaten Ogan Ilir.

Hasil penelitian menunjukkan bahwa tidak ada hubungan yang bermakna antara pengawasan berkala dengan kualitas bakteriologis air minum hasil pengolahan depot air minum di Kabupaten Ogan Ilir. Namun diketahui pula bahwa dari 40 pemilik/karyawan DAMIU yang menjadi responden, 29 orang $(72,5 \%)$ menyatakan bahwa pelaksanaan pengawasan berkala terhadap DAMIU tidak pernah dilakukan dalam beberapa tahun terakhir ini. Sedangkan sisanya $(27,5 \%)$ menyatakan bahwa pengawasan berkala dilaksanakan. Adapun pihak yang melakukan pengawasan berdasarkan hasil penelitian diketahui ialah dinas kesehatan setempat, dalam hal ini ialah Dinas Kesehatan Kabupaten Ogan Ilir.

Peran pemerintah dan pihak terkait yaitu dinas kesehatan sangatlah penting. Pengawasan terhadap penyelenggara usaha depot air minum isi ulang perlu ditingkatkan karena banyaknya depot yang tidak memeriksakan kualitas dari produk yang dihasilkan masih beroperasi bebas dan melayani konsumen. Pihak yang berwenang seharusnya lebih tegas dalam menindak lanjuti setiap depot air minum isi ulang yang tidak memenuhi syarat seperti yang telah ditetapkan oleh pemerintah. ${ }^{5}$

Selain itu, penting pula peran serta dari puskesmas sebagai pelayanan kesehatan terdekat dengan masyarakat. Berdasarkan hasil penelitian diketahui bahwa sampai saat ini pihak puskesmas sekitar belum pernah mengadakan penyuluhan maupun pelatihan mengenai higiene penjamah dan sanitasi depot air minum, baik kepada pemilik maupun karyawan depot yang ada. Pentingnya dari puskesmas untuk setiap tahunnya mempunyai program menginspeksi depot air minum isi ulang. Namun inspeksi dapat tidak dilakukan terhadap semua depot karena menggunakan sistem sampel. Hasil inspeksi secara langsung dapat diserahkan kepada Dinas Kesehatan Kabupaten. Namun yang juga menjadi hal penting ialah hasil tersebut juga perlu disampaikan kepada pemilik depot yang telah diinspeksi. Sehingga pemilik depot dapat mengetahui hasil higiene dan sanitasi sudah 
memenuhi syarat atau belum. Serta pihak puskesmas diharapkan bisa memberikan pembinaan kepada depot yang hasilnya belum memenuhi syarat, sehingga nantinya depot tersebut dapat menjadi lebih baik.

\section{Hubungan Higiene Personal Karyawan DAMIU dengan Kualitas Bakteriologis Air Minum Hasil Pengolahan Depot Air Minum di Kabupaten Ogan Ilir}

Berdasarkan hasil penelitian menunjukkan bahwa tidak ada hubungan yang bermakna antara higiene personal karyawan dengan kualitas bakteriologis air minum hasil pengolahan depot air minum di Kabupaten Ogan Ilir. Namun diketahui bahwa mayoritas karyawan DAMIU yang diteliti yaitu sebanyak 35 (87,5\%) di Kabupaten Ogan Ilir masih menerapkan higiene personal yang buruk dalam melakukan pengisian galon. Hanya sebagian kecil penjual sekaligus operator pada depot air minum yang mengerti tentang kebersihan baik pada tempat proses air, lingkungan sekitar, pakaian yang dikenakan, dan kebersihan diri sendiri. ${ }^{1}$ Mencuci tangan adalah hal kecil yang dapat dilakukan untuk menjaga kebersihan.

Pencemaran air minum dapat terjadi di tingkat produsen, penjual dan konsumen. Kurangnya pengetahuan dari penjual dan konsumen dalam hal kesehatan yaitu perlakuan terhadap air layak konsumsi misalnya penyimpanan air yang tidak memenuhi syarat, terkena sinar matahari secara langsung, tempat yang terlalu lembab dapat memicu pertumbuhan bakteri. ${ }^{5}$ Kondisi higiene penjamah ini meliputi semua hal yang digunakan dan dilakukan oleh karyawan. Dimulai dari kebersihan seragam, penggunaan tutup kepala, penggunaan celemek, penggunaan penutup mulut hingga kuku yang bersih. Selain itu juga dilihat perilaku karyawan seperti mencuci tangan, tidak meludah sembarangan, mengobrol, tidak makan dan minum, tidak merokok, dan tidak menggaruk selama kerja. Berbicara, makan, minum dan merokok pada saat bekerja berpotensi untuk terjadinya kontaminasi kuman yang berasal dari droplet karyawan. Berdasarkan penelitian Wandrivel diketahui bahwa mulut merupakan salah satu tempat bersarangnya bakteri, untuk itu sebaiknya menggunakan masker saat pengolahan agar tidak ada penyebaran bakteri dari mulut. ${ }^{3}$ Dari penelitian di lapangan masih ada yang memiliki kuku yang panjang dan tidak bersih pada saat melakukan pekerjaan, hal ini dapat menyebabkan perpindahan bakteri dari tangan ke air minum. Berdasarkan teori yang dikemukakan oleh Fathonah S bahwa kuku tangan sering menjadi sumber kontaminasi atau mengakibatkan kontaminasi silang. Sebagian besar karyawan tidak mencuci tangan dengan sabun sebelum melakukan pekerjaan sehingga dapat menimbulkan kontaminasi. $^{15}$

\section{Hubungan Kesehatan diri Karyawan DAMIU dengan Kualitas Bakteriologis Air Minum Hasil Pengolahan Depot Air Minum di Kabupaten Ogan Ilir}

Berdasarkan hasil penelitian menunjukkan bahwa tidak ada hubungan yang bermakna antara kesehatan diri karyawan dengan kualitas bakteriologis air minum hasil pengolahan depot air minum di Kabupaten Ogan Ilir. Namun diketahui bahwa mayoritas karyawan DAMIU yang diteliti yaitu sebanyak $39 \quad(97,5 \%)$ di Kabupaten Ogan Ilir termasuk ke dalam kategori kesehatan diri yang buruk. Kondisi kesehatan ini diukur melalui beberapa hal yaitu keadaan fisik secara umum sehat, bebas luka, bisul dan penyakit kulit, dan memeriksakan kesehatan setiap 6 bulan sekali. Secara umum terkait kondisi keadaan fisik dan penyakit kulit kondisi karyawan DAMIU termasuk baik. Namun dalam hal pemeriksaan kesehatan setiap 6 bulan sekali, diketahui dari seluruh karyawan yang menjadi responden hanya 1 orang yang menyatakan melakukan pemeriksaan kesehatan secara rutin. Tentu hal 
ini disebabkan oleh beberapa faktor, selain biaya yaitu pengetahuan dan kesadaran dari karyawan itu sendiri. Sesuai dengan Pedoman dan Pengawasan Higiene dan sanitasi depot air minum isi ulang, pengusaha depot harus memeriksakan kesehatan karyawannya minimal 6 bulan sekali. ${ }^{14}$ Pemeriksaan ini penting dilakukan untuk mencegah terjadinya kontaminasi pada air minum yang diproduksi apabila karyawan mengidap penyakit yang dapat ditularkan melalui udara atau droplet, misalnya TBC.

\section{Hubungan Fasilitas Cuci Tangan DAMIU dengan Kualitas Bakteriologis Air Minum Hasil Pengolahan Depot Air Minum di Kabupaten Ogan Ilir}

Berdasarkan hasil penelitian juga menunjukkan bahwa tidak ada hubungan yang bermakna antara ketersediaan fasilitas cuci tangan yaitu berupa sabun dan air mengalir dengan kualitas bakteriologis air minum hasil pengolahan depot air minum di Kabupaten Ogan Ilir. Diketahui pula bahwa mayoritas DAMIU yang diteliti yaitu sebanyak 35 (87,5\%) di Kabupaten Ogan Ilir tidak menyediakan fasilitas cuci tangan pada depot mereka. Fasilitas cuci tangan ini terdiri dari air bersih yang mengalir, air yang cukup secara kuantitas dan kualitas, sabun pembersih, serta lap atau kain pengering. Tersedianya fasilitas cuci tangan penting dalam rangka mendukung penerapan higiene personal karyawan yang baik, khususnya dalam mencuci tangan sebelum melakukan pengisian galon.

Purnawijayanti mengemukakan bahwa tangan yang kotor atau terkontaminasi dapat memindahkan bakteri dan virus patogen dari tubuh, feces, atau sumber lain ke makanan/minuman. ${ }^{17}$ Penelitian dilakukan di beberapa kota besar seperti Jakarta, Bandung, Medan dan Surabaya. Hasil penelitian di dua lembaga ini menunjukan bahwa air minum isi ulang terkontaminasi bakteri coliform, E. Coli, Salmonella. ${ }^{8,20}$ E coli yang terkandung pada air dapat dijadikan petunjuk bahwa air telah tercemar air oleh kotoran manusia. ${ }^{21}$ Mikrobamikroba ini dapat menyebabkan sakit yang lebih parah, termasuk infeksi intestinal, hepatitis, demam tifoid dan kolera. $^{22}$ Sedangkan air dari DAMIU sebagai air minum yang termasuk ke dalam golongan $\mathrm{A}$ seharusnya aman dari kontaminasi bakteri. ${ }^{23}$ Pencucian tangan dengan sabun diikuti dengan pembilasan akan menghilangkan mikroba yang terdapat pada tangan. Untuk bisa selalu mencuci tangan perlu disediakan fasilitas tempat mencuci tangan, sehingga karyawan dapat mencuci tangan sebelum bekerja. Sedangkan penjamah dan fasilitas akan sangat mempengaruhi pencemaran pada minuman. ${ }^{24,25}$

\section{KESIMPULAN DAN SARAN}

Berdasarkan pemeriksaan laboratorium ditemukan 13 DAMIU (32,5\%) yang sampel airnya positif mengandung bakteri koliform. Hasil analisis bivariat diperoleh bahwa variabel izin operasi, alat sterilisasi, sumber air baku, ruang pengisian, kebersihan DAMIU, tempat sampah, pemeriksaan bakteriologis, pakaian kerja, pelatihan penajmah makanan, pengawasan berkala, higiene personal, kebersihan diri dan fasilitas cuci tangan tidak memiliki hubungan yang bermakna dengan kualitas bakteriologis air. Meskipun demikian higiene dan sanitasi Depot Air Minum Isi Ulang (DAMIU) di Kabupaten Ogan Ilir masih tergolong ke dalam kategori buruk. Sehingga perlunya peningkatan pengetahuan dan kesadaran karyawan DAMIU mengenai higiene sanitasi. Disamping itu perlu ditunjang dengan adanya pengawasan dari dinas kesehatan. 


\section{DAFTAR PUSTAKA}

1. Achmadi, Umar Fahmi. Dasar-Dasar Penyakit Berbasis Lingkungan. Jakarta : Rajawali Press. 2012.

2. Soegianto, Agus. Ilmu Lingkungan Sarana Menuju Masyarakat Berkelanjutan. Surabaya: Airlangga University Press. 2010.

3. Wandrivel, Rido, Netty Suharti, Yuniar Lestari, 'Kualitas Air Minum Yang Diproduksi Depot Air Minum Isi Ulang Di Kecamatan Bungus Padang Berdasarkan Persyaratan Mikrobiologi', Jurnal Kesehatan Andalas. 2012; Vol. 1 (3) : 10-20.

4. Khoeriyah, Ari dan Anies, 'Aspek Kualitas Bakteriologis Depot Air Minum Isi Ulang (DAMIU) di Kabupaten Bandung Barat', MKB. 2015; Vol.47 (3): 15-25.

5. Walangitan, Maria R, MargarethSapulete, Jane Pangemanan, 'Gambaran Kualitas Air Minum Dari Depot Air Minum Isi Ulang Di Kelurahan Ranotana-Weru Dan Kelurahan Karombasan Selatan Menurut Parameter Mikrobiologi', Jurnal Kedokteran Komunitas dan Tropik. 2016; Vol. IV (7) : 40-55.

6. Lidya Ayu Natalia. Kajian Kualitas Bakteriologis Air Minum Isi Ulang Di Kabupaten Blora Melalui Metode Most Probable Number. Skripsi. Jurusan Biologi Fakultas Matematika Dan Ilmu Pengetahuan Alam Universitas Negeri Semarang. 2014.

7. Haryuni, Danti dan I Made Djaja. Analisis Kualitas Bakteriologis Air Minum Isi Ulang di Wilayah Kecamatan Cengkareng Jakarta Barat Tahun 20092014. Skripsi. Departemen Kesehatan Lingkungan Fakultas Kesehatan Masyarakat Universitas Indonesia. 2014.

8. Rumondor, Perisai P, John Porotu ,OliviaWaworuntu, 'Identifikasi Bakteri Pada Depot Air Minum Isi Ulang Di Kota Manado', Jurnal e-Biomedik (eBM). 2014; Vol. 2 (2): 16-23.

9. Efri Malisa Dwi Putri. Hubungan Higiene Sanitasi dengan Kontaminasi Bakteri Coliform Pada Air Minum Isi Ulang di Kecamatan Seberang Ulu 1 Kota Palembang Tahun 2015. Skripsi.
Fakultas Kedokteran dan Ilmu Kesehatan Universitas Islam Negeri Syarif Hidayatullah Jakarta. 2015.

10. Dinas Kesehatan Kabupaten Ogan Ilir. Profil Dinasi Kesehatan Kabupaten OganIlir Tahun 2016.

11. Murti, Bhisma. Desain dan Ukuran Sampel untuk Penelitian Kuantitatif dan Kualitatif di Bidang Kesehatan. Yogyakarta: Gadjah Mada University Press. 2010.

12. Pratiwi, Astri Wulandari, 'Kualitas Bakteriologis Air Minum Isi Ulang di Wilayah Kota Bogor', Jurnal Kesehatan Masyarakat Nasional. 2007; Vol 2. (2) : 45-57.

13. Fardiaz, Srikandi. Polusi Air dan Udara. Yoagyakarta; Kanisius. 2012.

14. Departemen Perindustrian dan Perdagangan RI. Keputusan Menteri Perindusrtian dan Perdagangan No. 651 Tahun 2004 tentang Persyaratan Teknis Depot Air Minum dan Perdagangannya. 2004.

15. Fathonah, S. Higiene dan Sanitasi Makanan. Semarang: Unnes Press. 2005.

16. Wulandari, Suci, Arum Siwiendrayanti, Anik SetyoWahyuningsih, 'Higiene Dan Sanitasi Serta Kualitas Bakteriologis DAMIU di Sekitar Universitas Negeri Semarang' Unnes Journal of Public Health. 2015; Vol. 4 (3) : 60-70.

17. Peraturan Menteri Kesehatan RI No.43 tahun 2014 Tentang Higiene Sanitasi Depot Air Minum.

18. Yunus, S.p. Umboh , J. Pinontoan, O, 'Hubungan Personal Higiene Dan Fasilitas Sanitasi dengan Kontaminasi Escherichia coli pada Makanan Padang Kota Manado dan Kota Bitung', JIKMU. 2015; Vol.5 (2): 70-88.

19. Purnawijayanti, H. Sanitasi, Higiene dan Keselamatan Kerja dalam Pengolahan Makanan, Kanisius, Yogyakarta. 2007.

20. Mukono. Prinsip Dasar Kesehatan Lingkungan. Surabaya : Airlangga University Press. 2006.

21. Sastrawijaya, Tresna. Pencemaran Lingkungan. Jakarta : Rineka Cipta. 2009.

22. Skipton, Sharon O. Drinking Water: Bacteria. Neb Guide. University of Nebraska-Lincoln Extenstion. 2014. 
23. Effendi, Hefni. Telaah Kualitas Air Bagi Pengelolaan Sumber Daya dan Lingkungan Perairan. Yogyakarta : Kanisius. 2003.

24. Kemenkes, RI. Pedoman Pelaksanaan Penyelenggaraan Hygiene Sanitasi Depot
Air Minum In : Lingkungan, D. P. (Ed). Jakarta. 2010.

25. Salvato, J. A. et al. Environmental Engineering. Canada : John Wiley \& Sons. Fifth Edition. 2003. 